\title{
Cerita Rakyat Ondorante Pembentuk Pola Perilaku dan Identitas Masyarakat
}

\author{
Laura Andri Retno M \\ Fakultas Ilmu Budaya, Universitas Diponegoro \\ lauraandrirm@yahoo.co.id
}

\begin{abstract}
Folklore has a position and a really important function for its proponent people. One of those folklores that exist in Pati, Central Java, is a folklore called Ondorante. In addition to completely describe the story, this research also intend to discover the transmission process and the funtions that appear in the Ondorante. Finally, through qualitative descriptive approach by interview, observation and bibliographical techniques, it appears that the folklore doesn't only play its role as an entertainment, education, reflection or ritual, but also offers a consciousness to the people about the past, about who were their ancestors and the origin of how their native land formed.
\end{abstract}

Keywords: folklore, description, transimission, funtion.

\section{Intisari}

Cerita rakyat memepunyai kedudukan dan fungsi yang sangat penting bagi masyarakat pendukungnya. Salah satu cerita rakyat yang terdapat di Pati Jawa Tengah adalah cerita rakyat Ondorante. Selain untuk mendeskripsikan cerita secara utuh, penelitian ini juga bertujuan untuk mengetahui proses transmisi dan fungsifungsi yang muncul dalam cerita rakyat Ondorante. Pada akhirnya, Melalui pendekatan deskritif kualitatif dengan teknik wawancara, observasi dan kepustakaan ditemukan bahwa cerita rakyat tersebut selain mempunyai fungsi sebagai hiburan, pendidikan, refleksi maupun ritual juga memberikan kesadaran pada masyarakatnya mengenai masa lalu, siapa tokoh yang menjadi nenek moyangnya dan bagaimana asal muasal daerahnya tersebut terbentuk.

Kata kunci : cerita rakyat, deskripsi, transmisi, fungsi.

\section{Pendahuluan}

Cerita rakyat merupakan bagian kebudayaan suatu kolektif yang diwariskan secara turun-temurun, secara tradisional dalam versi yang berbeda baik dalam bentuk lisan maupun contoh yang disertai gerak atau alat bantu pengingat (Dananjaya, 1994:2). Pada dasarnya setiap daerah mempunyai cerita rakyat yang dikenal secara turuntemurun. Cerita rakyat tersebut sangat berharga dan bernilai tinggi bagi kelompok masyarakatnya (folk-nya). Dalam cerita rakyat ditemukan tema dan makna simbolik 
tentang keteraturan sosial dan lingkungan. Ia bersifat fiktif dan anonim, tetapi membawa ajaran dan pesan-pesan tertentu. Ajaran dan pesan itu terselip di balik tindakan tokoh-tokohnya, baik ketika tokoh tersebut menghadapi masalah dan cara mengatasinya serta bagaimana memperjuangkan cita-citanya.

Cerita rakyat merupakan salah satu bentuk dari sastra lisan. Tak heran jika kemudian muncul berbagai versi dari sebuah cerita rakyat. Hal ini menjelaskan bahwa ingatan-ingatan orang terhadap cerita itu tidak sama, juga perbedaan perhatian pada unsur-unsur yang ada di dalamnya. Berbeda dengan cerita sejarah yang harus menunjukkan fakta-fakta, cerita rakyat tidak terpaku pada fakta-fakta yang terjadi tetapi lebih pada ingatan-ingatan orang. Nilai penting dari cerita rakyat terletak pada kesan-kesan, ingatan-ingatan, dan pemahaman mengenai apa yang pernah terjadi pada masa lampau sehingga menjadikan cerita itu tetap dikenang (Thohir, 200 7:101).

Sementara itu, mitos merupakan semacam takhayul sebagai akibat dari ketidaktahuan manusia tetapi bawah sadarnya memberitahukan tentang adanya suatu kekuatan yang menguasai dirinya dan alam lingkungannya. Bawah sadar inilah yang akhirnya menumbuhkan rekaan-rekaan dalam pikiran yang lambat laun berubah menjadi kepercayaan. Biasanya dibarengi dengan rasa ketakjuban, ketakutan, atau kedua-duanya. Reaksinya, timbul rasa hormat berlebihan yang melahirkan sikap pemujaan (kultus). Sikap pemujaan demikian ada kalanya dimanifestasikan ke dalam bentuk upacara keagamaan (ritus), yang dilakukan secara periodik dalam waktuwaktu tertentu (Timoer:1983:11). Sebagian isi mitos disosialisasikan dari mulut ke mulut di antara masyarakatnya secara turun-temurun yang kini kita kenal sebagai cerita rakyat. Karena dituturkan secara turun-temurun, maka isi mitos akan menjadi pengetahuan budaya (cultural knowledge), sehingga dianggap oleh suatu kelompok masyarakat sebagai kisah yang benar-benar terjadi, tetapi hanya dianggap sebagai dongeng yang tidak diyakini kebenarannya oleh sebagian masyarakat yang lain.

Desa Parenggan yang terletak di Kabupaten Pati Jawa Tengah memiliki cerita rakyat yang oleh sebagian besar masyarakat diyakini kebenarannya. Cerita rakyat Ondorante (CRO) adalah cerita yang tersebar secara turun temurun dan berkaitan erat dengan perilaku serta kebiasaan masyarakatnya sehari-hari.

\section{Metode Penelitian}


Penelitian ini adalah penelitian kualitatif yaitu jenis penelitian yang temuantemuannya tidak melalui prosedur statistik dan bentuk hitungan lainnya. Penelitian kualitatif adalah penelitian yang digambarkan dengan kata-kata atau kalimat yang dipisahkan menurut kategori untuk memperoleh kesimpulan. Penelitian juga dilakukan dengan teknik pengumpulan data seperti wawancara, observasi dan kepustakaan. Teknik pengumpulan data adalah cara kerja bersistem untuk mempermudah melakukan suatu kegiatan penelitian guna mencapai tujuan yang diinginkan.

\section{Pembahasan}

\section{Deskripsi Cerita Rakyat Ondorante}

Pada masa pemerintahan Mataram dengan rajanya Sultan Agung, di Pesantenan tepatnya Sitinggil tinggal seorang yang sakti bernama Kyai Ondorante. Oleh rakyatnya, sosok tersebut dianggap pintar karena memiliki kesaktian yang luar biasa. Lelaki asli Sitinggil ini berwatak kaku, jujur, kolot (bagel) dan semaunya sendiri. Selain mempunyai kegemaran minum minuman keras dan sabung ayam, ada watak positif yang dimilikinya, yaitu sikap tegas, tidak mau dipengaruhi, tepo seliro, rasa kerukunan yang besar dan keinginan untuk selalu membantu orang lain.

Kehidupan di Padepokan Sitinggil dan sekitarnya sangatlah tentram hingga suatu ketika agama Islam masuk ke Jawa, tanpa terkecuali daerah kekuasaan Kyai Ondorante. Suasana yang damai seketika berubah menjadi kacau manakala pemimpin mereka, Kyai Ondorante, merasa terusik ketenangannya dan tidak cocok dengan tata cara ibadah agama baru tersebut. Ia merasa aneh melihat adat kebiasaan masyarakat yang mengumandangkan adzan sebagai tanda panggilan sholat seperti berteriak-teriak menyebut lawa bubar-lawa bubar, memakai pakaian putih-putih (rukuh) seperti pocong sambil komat-kamit dan memukul kulit binatang yang direntangkan di atas kurungan (bedug). Kyai Ondorante merasa bahwa masyarakat yang biasanya tunduk padanya mulai diserang wabah penyakit gila.

Kyai Ondorante merasa terusik dan mulai bersikap kasar. Upaya menghentikan kebiasaan masyarakat dilakukan mulai dengan cara halus, menegur. Tetapi karena kebiasaan itu merupakan suatu kewajiban ibadah, maka mereka tidak mempedulikan teguran sang Kyai dan terus menjalankan kewajibannya sebagaimana 
umat beragama. Merasa tegurannya tidak ditanggapi, Kyai Ondorante sakit hati dan mulai bersikap anarkhis. Ia mengganggu masyarakat yang sedang beribadah di masjid, melempari batu, membunyikan kentongan keras-keras dan mengancam akan membunuh jika mereka tetap bersikeras melakukan kebiasaan baru itu. Karena ketakutan dan merasa nyawanya terancam, banyak masyarakat Sitinggil yag melarikan diri mencari perlindungan.

Kekacauan yang terjadi di Sitinggil terdengar sampai telinga Patih Sombo Pradam. Lalu datanglah Patih ke tempat Kyai Ondorante dengan maksud membujuk sang Kyai agar mau menghentikan kejahatannya. Upaya Patih gagal karena Kyai Ondorante tetap bersikeras bereaksi apabila masyarakat masih mengganggu ketenangannya. Pertemuan antara Patih dengan sang Kyai akhirnya berbuntut peperangan. Perang yang dimenangkan Kyai Ondorante menimbulkan banyak korban. Hingga kemudian Kyai Ondorante memberi nama daerah itu "Parenggan" yang artinya tempat atau ajang peperangan.

Karena kekalahannya, Patih Sombo Pradam melaporkan Kyai Ondorante kepada Adipati Pati, Mangun Oneng. Adipati dan istrinya, Roro Siu, berembug membahas masalah tersebut. Kemudian Adipati Pati memutuskan untuk menemui Kyai Ondorante di padepokannya. Sama halnya dengan sang Patih, niat Adipati juga gagal total. Kyai Ondorante bersikeras menolak menghentikan perbuatannya, bahkan kebiasaan mengganggu warga semakin sering dilakukan dan tidak segan-segan membunuh siapa saja yang menentangnya. Peperangan antara Adipati dengan sang Kyai tidak dapat dihindarkan lagi. Adipati kalah dan lari ke Mataram melapor pada Sultan Agung.

Sesampainya di Mataram, Adipati Mangun Oneng menyampaikan duduk permasalahan yang terjadi. Sultan Agung semakin prihatin mendengarnya. Bertepatan dengan itu, datang seorang Sunan dari Tuban, yaitu Sunan Makhdum Alatas. Kedatangannya bermaksud untuk menyebarkan agama Islam di Mataram dan sekitarnya. Setelah Sunan mendengar masalah yang dihadapi Adipati Pati, ia menawarkan diri untuk menghadapi Kyai Ondorante. Niat baik itu disambut gembira oleh Sultan Agung dan Adipati Pati. Kemudian bergegaslah sang Sunan ,menuju padepokan Sitinggil. 
Setelah sampai di padepokan, Sunan Makhdum membangun rumah dan surau yang berada tidak jauh dari tempat tinggal Kyai Ondorante. Selang beberapa hari, Sunan berkunjung ke tempat sang Kyai dan berpura-pura bertanya mengenai persoalan yang terjadi. Penjelasan Kyai Ondorante tidak memuaskan hati Sunan, lalu terjadilah perang.

Sunan Makhdum yang dibantu oleh muridnya, Sunan Kinting, tidak dapat menundukkan Kyai Ondorante. Akhirnya Sunan Makhdum memohon pada Allah untuk mati sempurna karena merasa tidak mampu mengatasi sang Kyai. Jasad Sunan Makhdum dimakamkan dipadepokannya. Oleh masyarakat, tempat itu kemudian dikenal dengan nama desa Makhdum. Saat ini desa tersebut telah berubah menjadi pemakaman umum Makhdum dan masih termasuk dalam wilayah desa Parenggan.

Kegagalan Sunan Makhdum menimbulkan keprihatinan Sultan Agung hingga akhirnya datang Syekh Jangkung ke Mataram. Sultan Agung menceritakan keributan yang terjadi di Pesantenan Pati dan mengutus Syekh Jangkung menyelesaikan masalah tersebut. Tugas berat itu diterima Syekh Jangkung dengan senang hati. Ia yang terkenal memiliki kesaktian luar biasa ini kemudian pergi menuju Pesantenan Pati.

Sesampainya di Pesantenan Pati, Syekh Jangkung menemui Adipati Mangun Oneng dan menyampaikan rencananya untuk mengelabui Kyai Ondorante. Rencana itu disambut baik oleh sang Adipati. Mereka berdua pergi menemui Patih Sombo Pradam untuk meminjam anak perempuannya yang cantik bernama Guranti. Setelah Patih dan Guranti bersedia membantu Syekh Jangkung dalam melaksanakan siasatnya, pergilah Guranti yang diikuti Syekh Jangkung dari kejauhan menemui Kyai Ondorante di padepokannya.

Kedatangan Guranti yang berpura-pura menjual tuak itu disambut baik oleh Kyai Ondorante. Kyai Ondorante yamg gemar minum tuak itu terpikat pula oleh kecantikan dan kemolekan Guranti. Seperti yang diamanatkan Syekh Jangkung, Guranti terus merayu Kyai Ondorante hingga akhirnya sang Kyai mabuk dan lengah. Kesempatan ini digunakan Guranti untuk mengetahui kelemahan dari Kyai. Tanpa curiga, ia menceritakan semua kelemahannya bahwa di balik kesaktiannya, Kyai hanya bisa mati jika kedua tangannya diikat dengan rantai emas, kaki kanan kirinya dikaitkan pada sepasang gajah putih, dan ditarik dengan arah yang berlawanan. 
Untuk mengagetkan gajah itu, ubun-ubunnya harus dipecut sehingga gajah lari kencang dan tubuh kyai terbelah menjadi dua bagian (badan sebelah kanan dan sebelah kiri). Kemudian jasadnya harus dikubur secara terpisah yang dibatasi oleh sungai agar tubuh itu tidak menyatu dan hidup kembali.

Mendengar itu semua, Syekh Jangkung yang berada tidak jauh dari rumah Kyai Ondorante langsung mengikat tubuh sang Kyai dan membawanya ke kadipaten. Setelah menyerahkan Kyai Ondorante kepada Adipati Pati dan Patihnya, Syekh Jangkung pergi ke Mataram untuk meminjam sepasang gajah putih milik Sultan.

Syekh Jangkung kembali ke Pesantenan dengan membawa sepasang gajah putih. Lalu tubuh Kyai Ondorante diikat dengan rantai emas dan kedua kakinya diikat pada sepasang gajah itu. Terbelahlah tubuh sang Kyai menjadi dua bagian dan jasadnya dikuburkan pada tempat yang terpisah. Bagian tubuh yang satu berada Gemeces Kalidoro dan satunya lagi berada di Nggethakan. Konon, nama Nggethakan ini berhubungan dengan tempat sepasang gajah itu dikagetkan (digethak ubunubune), sehingga oleh masyarakat daerah ini dinamakan Nggethakan yang berasal dari kata nggethak atau membentak. Sampai saat ini daerah tersebut masih bernama desa Nggethakan.

Seekor gajah lain terus berlari ke arah selatan, kemudian berhenti di suatu tempat dan mati. Oleh masyarakat, daerah tersebut dikenal dengan nama desa Gajahmati. Sementara, sungai yang menjadi pemisah kedua makam Kyai Ondorante disebut dengan Sungai Kraten atau Kali Kraten.

\section{Penyebaran Cerita (transmisi), Penyampai Cerita dan Pendengar (Audiens)}

Desa Parenggan Pati merupakan desa dengan penduduk sebagian besar memeluk agama Islam. Namun dalam kenyataan kehidupan sehari-hari mereka masih tetap melakukan kebiasaan leluhurnya secara turun temurun seperti mo limo (madat, madon, mabuk, main,dll. Masyarakat Parenggan dibagi menjadi masyarakat santri dan abangan. Kepercayaan mereka terhadap CRO dapat dikategorikan dalam dua golongan. Golongan yang tidak atau kurang percaya terhadap $C R O$ yaitu golongan santri. Sedang golongan yang percaya terhadap $C R O$ adalah golongan abangan. Golongan abangan ini mewujudkan rasa percaya mereka dalam bentuk tradisi sedekah bumi dan khol yang mereka lakukan setiap tahunnya sebagai bentuk ritual penghormatan pada leluhur. 
CRO tersebar, ditransmisikan dari mulut ke mulut secara lisan dari satu generasi ke generasi berikutnya. Bagi masyarakatnya, $C R O$ bukanlah hal yang tabu untuk diceritakan. Sebagian besar dari warga menyatakan bahwa $C R O$ tidak pantang untuk disebarkan, tidak ada aturan tentang waktu atau hari tertentu dan oleh orangorang tertentu yang berhak atau pantas menceritakan cerita tersebut. Orang-orang tua bebas bercerita kepada anak cucunya tentang siapa Ondorante. Bagi masyarakat abangan, $C R O$ dianggap sebagai cerita yang sakral berkaitan dengan tokoh utama cerita dipercaya sebagai "mbahurekso" desa Parenggan. Tidak ada perlakuan khusus dalam cerita, artinya ia dapat diungkapkan kapan saja, dimana saja dan pada siapapun juga. Tidak ada momen khusus ataupun ritual-ritual yang mengawali cerita. Ia bebas diungkapkan dan didengarkan oleh masyarakat dari golongan manapun dan usia berapapun.

Hanya saja bagi mereka yang bukan merupakan masyarakat abangan atau notabene warga pendatang, merasa risih atau tidak berkenan jika cerita tersebut disebarluaskan. Meski sebagian mengakui $C R O$ mengandung nilai sejarah, tetapi ia memuat versi negatif yang tidak pantas ditiru atau dilakukan. Masyarakat golongan santri lebih memilih untuk tidak terlibat dalam proses penyebaran cerita karena mereka beranggapan bahwa $C R O$ adalah cerita yang dilarang, dianggap tabu untuk diceritakan.

Peranan orang tua dalam pewarisan cerita cukup besar, rata-rata masyarakat menyatakan bahwa mereka mendengar cerita tersebut dari orang tua. Sementara itu sisanya berasal dari suami, teman, atau sumber lain. Dalam hal ini terlihat bahwa dalam masyarakat dimana tercipta sistem keluarga, maka dalam sistem keluarga itu secara langsung atau tidak terbina sedini mungkin hal-hal yang berhubungan dengan naluri pewarisan individu dan kebudayaannya.

Dengan demikian tidaklah mengherankan apabila generasi keturunan mereka, secara langsung atau tidak, selalu terkondisikan ke arah permasalahan perkembangan cerita dan upacara-upacara yang berhubungan dengan cerita. Sebab dengan terulangnya kembali pelaksanaan upacara berkaitan dengan cerita, secara langsung atau tidak, berpengaruh terhadap upaya pewarisan unsur budaya yang ada. 


\section{Fungsi dari Cerita Rakyat Ondorante}

Sebagaimana umumnya, cerita-cerita rakyat selalu menggunakan alur lurus. Ceritacerita rakyat selalu mengandung fungsi yang hendak disampaikan oleh penuturnya. Fungsi dalam cerita rakyat itu biasanya tersirat di dalam peristiwa-peristiwa yang dialami oleh si tokoh utama cerita rakyat tersebut.

Pada umumnya cerita rakyat memiliki nilai-nilai sendiri, termasuk ajaran norma sosial, agama beserta sikap dan nilai-nilai kebudayaan masyarakat pendukungnya serta penyampaian gagasan yang mengandung pembangunan mental manusia. Cerita rakyat berfungsi sebagai pengungkap tentang masyarakat, bagaimana folk-nya berfikir. Selain itu cerita rakyat juga berguna untuk mengabadikan segala sesuatu

$C R O$ merupakan kisah perlawanan tokoh Ondorante (antagonis) menghadapi kekuasaan Mataram, dalam hal ini Sunan Makhdum dan Syeh Jangkung (protagonis). Ketiga tokoh tersebut seperti melambangkan kecenderungan di dalam kehidupan manusia, yaitu bersaing mempertahankan kepercayaan atau keyakinannya. Mereka mempergunakan kesaktian untuk mempertahankan kepercayaan dan keyakinan itu.

Unsur menarik dari cerita ini adalah konflik yang terjadi di antara tokohtokohnya. Ondorante berperan sebagai tokoh antagonis sekaligus pencipta ketegangan dan teror pada masyarakat yang berbeda kepercayaan dan keyakinan dengannya, sehingga muncul unsur hiburan dan pendidikan (didaktik) dalam cerita rakyat tersebut.

\section{Fungsi hiburan}

$C R O$ berfungsi sebagai hiburan bagi masyarakat pendukungnya. Cerita ini mampu memberi suatu cara pelarian yang menyenangkan dari dunia nyata yang penuh kesukaran, sehingga dapat mengubah pekerjaan yang memberatkan menjadi sesuatu yang mengasyikkan. Terdapat ungkapan bahwa tokoh Ondorante hanya bisa mati jika tubuhnya diikat menggunakan rantai emas yang dikaitkan dengan sepasang gajah putih, sehingga tubuhnya terbelah menjadi dua dan dikubur pada tempat yang dipisahkan oleh aliran sungai. Ungkapan itu secara tidak langsung baik disadari maupun tidak merupakan bagian yang menghibur. Mengajak pendengar berimajinasi sejenak keluar dari dunia nyata dan masuk dalam dunia khayal. Imajinasi itu 
memuat sesuatu yang tidak mungkin terjangkau oleh nalar manusia menjadi mungkin terjadi.

\section{Fungsi pendidikan (didaktik)}

Unsur pendidikan dalam cerita rakyat Parenggan ini terlihat pada kesediaan Sunan Makhdum dan Syekh Jangkung menumpas Ondorante. terlebih saat Sunan Makhdum bersedia melakukan bunuh diri setelah mengakui kekalahannya pada Ondorante. Selain itu, unsur pendidikan juga muncul pada cara penyelesaian masalah oleh Syekh Jangkung yang menggunakan kepandaiannya mengelabui Ondorante hingga akhirnya Ondorante dapat ditumpas. Pesan yang hendak disampaikan dalam cerita ini adalah sikap jujur dan ksatria yang ditunjukkan oleh Sunan Makhdum setelah mengakui kekalahannya, manusia menjauhkan diri dari tindakan-tindakan kekerasan, dan bersamaan dengan itu orang hendaknya juga sadar bahwa adanya dua karakter manusia seperti yang terwakili oleh Ondorante (antagonis) dengan Sunan Makhdum dan Syekh Jangkung (protagonis), sehingga terserah kepada masyarakatnya siapa di antara ketiganya yang dijadikan teladan dalam hidupnya.

\section{Fungsi pencerminan/refleksi}

Fungsi refleksi atau pencerminan ini berkaitan dengan $C R O$ sebagai alat pengesah pranata dan kebiasaan masyarakatnya. Dalam kehidupan nyata di lapangan, karakter yang melekat pada tokoh Ondorante (digambarkan sebagai tokoh yang kaku, keras, memiliki kebiasaan bermain judi, mabuk dan main perempuan tetapi sakti) sangat dijiwai oleh masyarakatnya. Karakter tersebut meneguhkan kepercayaan mereka dan menumbuhkan rasa kebanggaan sebagai salah satu keturunan Ondorante.

Selain itu cerita ini memberikan pengesahan untuk membenarkan atas kebiasaan atau tingkah laku yang dilakukan secara bersama-sama oleh masyarakat, seperti bermain kartu, mabuk, main perempuan atau perilaku menyimpang lain yang diidentikkan dengan tokoh Ondorante, sehingga setiap muncul cerita negatif tentang masyarakat Parenggan Pati maka orang lain akan selalu menyatakan "pancen keturunane Ondorante".

\section{Fungsi ritual}

Tokoh Ondorante dan Sunan Makhdum oleh masyarakatnya dipercaya sebagai cikal bakal desa Parenggan, sehingga makam keduanya dikeramatkan. Konsep keramat di sini berarti tempat yang dimuliakan dan oleh karenanya orang tidak bisa bertindak 
seenaknya sendiri di sekitar makam. Ondorante semasa hidupnya tinggal di Sitingggil). Saat ini, daerah tersebut dikenal sebagai pemakaman umum Sentono Gading sedangkan Sunan Makhdum dimakamkan di makam Makhdum. Untuk memperingatinya maka setiap tanggal 10 Suro selalu diadakan khol di kedua makam tokoh tersebut.

Namun demikian tata cara khol di kedua makam itu sangat berbeda. Pada makam Makhdum, khol diisi dengan membaca tahlil, Al Qur'an dan rebana yang dilakukan oleh masyarakat selama tiga malam berturut-turut. Sementara di makam Sentono Gading, Khol diisi dengan pertunjukan barongan, yaitu kesenian semacam reog atau jathilan di depan makam dan biasanya dilakukan pada sore hari. Malam harinya, masyarakat yang berada di daerah tersebut bermain kartu dan begadang sampai pagi (melek-melek). Pertunjukan barongan adalah kesenian khas Pati yang ternyata digemari oleh Ondorante. Masyarakat berharap dengan pertunjukan barongan ini dapat terjalin hubungan yang baik antara leluhur dan masyarakatnya.

\section{Simpulan}

Cerita rakyat yang bertema asal-usul daerah selain mempunyai fungsi sebagai hiburan, pendidikan, refleksi maupun ritual juga memberikan kesadaran pada masyarakatnya mengenai masa lalu, asal muasal daerah tersebut terbentuk, siapa tokoh yang menjadi nenek moyangnya, serta peristiwa-peristiwa luar biasa yang dialami tokoh.

Melalui pengetahuan dan pemahaman itulah masyarakat berusaha untuk mengidentifikasikan dirinya sebagai keturunan dari nenek moyangnya. Disamping itu, cerita rakyat yang melekat pada masyarakat baik alur, tokoh maupun kejadiankejadiannya membentuk suatu ingatan bagi masyarakat yang bersangkutan dengan asal-usul, identitas, dan superioritas kelompok. Munculnya rasa bangga pada tempat kelahiran, cinta terhadap kelompoknya mampu menumbuhkan persatuan dan kesatuan yang utuh pada mereka.

Rasa menghargai yang tinggi akan muncul apabila mereka paham betul dari mana dan oleh siapa mereka berasal. Juga kebersamaan akan tumbuh apabila mereka mengerti bahwa diberbagai banyak wajah ada persamaan darah yang mengalir pada 
jiwa mereka. Di sinilah cerita rakyat menjadi sangat penting, karena pada akhirnya masyarakat menjadi tahu tentang identitas diri dan kelompoknya.

\section{Daftar Pustaka}

Ahimsa-Putra, Heddy Shri. 2001. Strukturalisme Levi-Strauss: Mitos dan Karya Sastra. Malang: YAA.

Damono Sapardi Djoko. 2005. Pegangan Penelitian Sastra Bandingan. Jakarta : Pusat Bahasa.

Dananjaya, James. 1994. Folklor Indonesia: Ilmu Gosip, Dongeng, dan lain-lain. Jakarta: Pustaka Utama Grafiti.

Endraswara, Suwardi. 2005. Tradisi Lisan Jawa: Warisan Abadi Budaya Leluhur. Yogyakarta: Narasi.

Hutomo, Suripan Hadi. 1991. Mutiara yang Terlupakan Pengantar Studi Sastra Lisan. Jatim: MeDPress. Surabaya: Gaya Masa.

Martini, Laura Andri Retno. 2002. "Rakyat Ondorante bagi Masyarakat Parenggan Pati.” Semarang: Skripsi Jurusan Sastra Indonesia Fakultas Sastra Universitas Diponegoro.

Moleong, Lexy J. 2002. Metodologi Penelitian Kualitatif. Bandung: PT. Remaja Rosdakarya

Susanto, P.S. Harry. 1987. Mitos Menurut Mircea Eliade. Yogyakarta: Kanisius.

Thohir, Mujahirin. 2007. Memahami Kebudayaan; Teori, Metodologi, dan Aplikasi. Semarang: Fasindo.

Timoer, Sunarto. 1983. Mitos Çura Baya; Cerita Rakyat sebagai Sumber Penelitian Sejarah. Jakarta: Balai Pustaka.

Teeuw, A. 1984. Sastra dan Ilmu Sastra. Jakarta: Pustaka Jaya. 